\title{
O dispositivo escolar republicano na paisagem das cidades brasileiras: enunciados, visibilidades, subjetividades
}

\section{The republican school device in the landscape of Brazilian cities: statements, visibility, subjectivities}

\author{
Maria do Rosário GREGOLIN \\ Universidade Estadual Paulista (UNESP) /CNPQ
}

\begin{abstract}
RESUMO: Nos primeiros anos da República brasileira, a paisagem das cidades foi alterada pela instalação de prédios escolares suntuosos: inaugurava-se a rede de um dispositivo de saber e de poder (FOUCAULT, 1999) que atendia às exigências históricas de construção da identidade nacional, com base nos ideais positivistas de ordem, progresso, higiene, civilidade etc. A instalação desse dispositivo coincidiu com o início da ampliação dos usos sociais da fotografia no Brasil. Muitas instituições produziram suas imagens fotográficas e fixaram uma memória iconográfica dos espaços escolares e das práticas discursivas desenvolvidas no interior dessa rede de saber e de poder. O objetivo deste artigo é mobilizar o conceito foucaultiano de dispositivo para analisar as curvas de visibilidade e de enunciabilidade, as linhas de força e os jogos de subjetividades como elementos de constituição da escola republicana como um dispositivo que atendeu às urgências políticas de um certo momento da construção identitária do Brasil.
\end{abstract}

PALAVRAS-CHAVE: Foucault; dispositivo escolar; subjetivação; prática discursiva; fotografia.

ABSTRACT: In the early years of the Brazilian Republic, the landscape of cities was changed by installing lavish school buildings: the network was inaugurated as a device knowledge and power (FOUCAULT, 1999) who went to the historical demands of national identity construction based the positivist ideas of order, progress, hygiene, civility etc. Installing this device coincided with the beginning of the expansion of the social uses of photography in Brazil. Many institutions produced their photographic images and set an iconographic memory of school spaces and discursive practices developed within this network of knowledge and power. The purpose of this article is to mobilize Foucault's concept of device to analyze the curves of visibility and curves of enunciation; lines of forces and subjectivities games as constituting elements of the republican school as a device that met the political urgencies of a certain time of identity construction in Brazil.

KEY WORDS: Foucault; school device; subjectivity; discursive practice; photography.

\section{Introdução}

A descrição do arquivo dissipa essa identidade temporal em que gostamos de nos olhar para conjurar as rupturas da história; ela rompe os fios das teleologias transcendentais e no lugar onde o pensamento antropológico interrogava o ser do homem ou a sua subjetividade, ela faz com que se manifeste o outro, o que está do lado de fora. O diagnóstico, assim entendido, não estabelece a autenticação de nossa identidade pelo jogo das distinções. Ele demonstra que nós somos diferença, que a nossa razão é a diferença dos discursos, a nossa história a diferença dos tempos, o nosso eu a diferença das máscaras. Que a diferença, longe de ser origem esquecida e recoberta, é a dispersão do que somos e do que fazemos.

Michel Foucault 
Há décadas a obra de Michel Foucault vem sendo objeto de investigação em muitos domínios do saber, sob diversas perspectivas. A abrangência de suas temáticas e a perspicácia de suas problematizações desafiam os limites disciplinares e instigam uma pluralidade de leituras sob diferentes regimes de apropriação. A perspectiva que temos adotado nos leva a ler Foucault pela via da linguagem, tomando o discurso como categoria central do seu pensamento. Apesar dessa centralidade da problemática discursiva, Foucault nunca pretendeu elaborar uma teoria do discurso mesmo que, em certos momentos de sua obra, tenha afirmado isso explicitamente:

Eu me dei como objeto uma análise do discurso [...] O que me interessa no problema do discurso é o fato de que alguém disse alguma coisa em um dado momento. Isto é o que eu chamo de acontecimento. Para mim, trata-se de considerar o discurso como uma série de acontecimentos, de estabelecer e descrever as relações que esses acontecimentos - que podemos chamar de acontecimentos discursivos - mantêm com outros acontecimentos que pertencem ao sistema econômico, ou ao campo político, ou às instituições (FOUCAULT, 2003, p. 255-256)

Se ele não pretendeu produzir uma teoria discursiva, podemos, então, pensar uma análise de discurso com Foucault? As pesquisas que vimos desenvolvendo há cerca de vinte anos tem-nos indicado que sim porque as problemáticas foucaultianas estão, sempre, articuladas a uma reflexão sobre os discursos: pressupondo que as coisas não preexistem às práticas discursivas, Foucault entende que estas constituem e determinam os objetos. É, pois, a partir da reflexão sobre as transformações históricas do fazer e do dizer na sociedade ocidental - práticas discursivas que provocam fraturas, brechas e rearranjos nas configurações do saber-poder - que se edifica o pensamento foucaultiano. Essa busca pelos discursos ele não a faz em um lugar disciplinar estabelecido: não está centralmente na Filosofia, na Antropologia, na História - apesar de questionar os métodos e as concepções fundamentais desses campos - e, muito menos, na Linguística, apesar de pensar sobre a linguagem, dialogar conflituosamente com Saussure e nunca ter deixado de considerar como central a ideia de que são os dizeres que constituem os objetos de que falam.

A teoria do discurso subjacente às propostas foucaultianas deriva do seu objetivo fundamental de compreender como se articulam os processos de subjetivação e as verdades no âmbito da produção discursiva. É importante ressaltar que subjetividade, para Foucault, não significa que o sujeito seja pensado como categoria ontologicamente invariável; ao contrário, ele a entende de maneira complexa, como processos de subjetivação modificáveis e plurais. Assim, uma análise de discursos com Michel Foucault convida à construção de objetos discursivos numa tríplice tensão entre a sistematicidade da linguagem, a descontinuidade da história e instabilidade da produção de subjetividades.

Ao entrelaçar o discurso, a verdade e a subjetividade, os estudos de Foucault são profundamente históricos, entranhados na busca por responder a uma questão candente: quem somos nós, hoje? O que interessa a Foucault "é o que se passa, o que somos e fazemos hoje: próxima ou longínqua, uma formação histórica só é analisada pela sua diferença conosco, e para delimitar essa diferença" (DELEUZE, 1992a, p. 142). Sua intenção não é realizar um retorno ao passado, mas antes diagnosticar sua própria atualidade. Esse diagnóstico do presente, entretanto, não se contenta em caracterizar o 
que somos hoje, mas também tem por função apontar como o que é poderia não mais ser o que é.

Foucault ocupa-se da verdade na medida em que pensa sobre a vontade de verdade que anima os valores de uma sociedade em um certo momento histórico. Ao mesmo tempo, ao examinar os mecanismos sociais que controlam a produção e a circulação dos discursos, Foucault nos mostra que a vontade de verdade se apoia em uma base institucional, sendo "ao mesmo tempo reforçada e reconduzida por toda uma espessura de práticas como a pedagogia, o sistema dos livros, da edição, das bibliotecas, as sociedades de sábios outrora, os laboratórios hoje" (FOUCAULT, 1971, p. 20). Por isso, aponta Foucault, o modo mais profundo do exercício da vontade de verdade é a maneira como o saber é disposto numa sociedade, como é valorizado, distribuído, repartido e, de certa forma, atribuído.

É particularmente essa ideia central de Foucault sobre a espessura de práticas históricas que enlaçam o saber e o poder que sustenta o propósito deste artigo ao analisar práticas discursivas inscritas em imagens fotográficas que organizaram a constituição do dispositivo escolar no Brasil, nos primeiros anos da República. Nossa hipótese é que essas práticas discursivas produziram subjetividades na medida em que materializaram sentidos do ideário republicano a fim de promover o progresso e a correção da incivilidade do sujeito brasileiro. Assim, o objetivo deste artigo é analisar algumas dessas práticas discursivas fixadas em fotografias que organizaram a constituição da rede escolar. Nosso objeto de análise são álbuns fotográficos produzidos pela Escola Normal (Caetano de Campos, São Paulo, SP) nos anos de 1895 e 1908 e que constituíram uma "escrita da história" dessa instituição a partir dos retratos de sua arquitetura, de seus espaços e de suas práticas escolares. Por meio delas produziu-se uma memória das técnicas de normalização e disciplina dos corpos investidas no espaço e no tempo das atividades escolares. Este artigo analisa, portanto, a partir do conceito foucaultiano de dispositivo, as curvas de visibilidade e de enunciação, as linhas de força e os jogos de produção de subjetividades investidos na escolarização dos saberes no Brasil em um certo momento de sua história.

\section{A arquegenealogia foucaultiana}

No início de seu texto "O sujeito e o poder" (1995), Foucault sintetiza os objetivos de sua investigação desde os anos 1960 e afirma que o seu grande tema sempre foi a produção de uma história dos diferentes modos de subjetivação do ser humano na cultura ocidental. Essa história, que envolve o poder e a produção de saberes, é percorrida, na obra foucaultiana, a partir de três modos de produção histórica das subjetividades. Em um primeiro momento, que foi denominado como arqueologia do saber, Foucault pesquisou diferentes campos de investigação que buscam constituirse como ciência e que produzem, como efeito, a objetivação do sujeito; dessa perspectiva, voltou-se para a história da loucura, da medicina e de campos do saber que trataram dos temas da vida, da linguagem e do trabalho (História da Loucura na Idade Clássica; O Nascimento da Clínica; As Palavras e as Coisas). Nesse momento, que se desenvolve ao longo dos anos 1960, investigou os saberes que embasam a cultura ocidental e por meio do método arqueológico buscou revolver a história desses saberes (A Arqueologia do Saber; A ordem do discurso). Em um segundo momento, que abrange a década de 1970, Foucault estudou práticas (discursivas e não discursivas) que produziram a objetivação do sujeito por meio de técnicas disciplinares como a classificação e a segregação. Ele empreende, então, a análise das articulações entre os saberes e os poderes, a partir de uma genealogia do poder (Vigiar e Punir); deriva 
dessas análises a ideia de que nossa sociedade se organiza em uma microfísica do poder (FOUCAULT, 1979). Enfim, em um terceiro momento, nos anos 1980, investigou processos de subjetivação a partir de técnicas de si e da governamentalidade, isto é, do governo de si e dos outros, orientando suas pesquisas na direção da sexualidade, da constituição histórica de uma genealogia da ética (História da Sexualidade, em três volumes).

Esse percurso abrangente, que envolveu a problematização das relações entre saberes e poderes na história da sociedade ocidental, abriu-se em várias direções a fim de compreender a construção histórica das subjetividades. Apesar dessa amplitude temática, há uma profunda organicidade na obra foucaultiana pois a articulação entre discurso, verdade e sujeito é uma temática constante em todo o seu trajeto. Assim sendo, não há o abandono de temas fortemente arqueológicos, como as noções de enunciado, formação discursiva e arquivo, a partir do momento em que se dedica à genealogia (do poder; da ética): vemos com nitidez, por exemplo, em seus últimos escritos na História da sexualidade, a correlação entre os discursos, as práticas de poder e os jogos de verdade que embasam os procedimentos de subjetivação. Da mesma forma, a questão do poder sempre esteve presente apesar de aparecer explicitamente teorizado a partir de 1970, em A ordem do discurso, e se tornar central nos trabalhos da genealogia.

Pensando nessa organicidade dos temas e reflexões, podemos, então, compreendê-lo em termos de uma arquegenealogia, sendo o primeiro momento aquele em que, procurando estabelecer a constituição dos saberes em articulação com as práticas sociais, busca responder à questão: como os saberes aparecem e se transformam? A genealogia complementa o exercício arqueológico, sendo então um momento em que Foucault busca o porquê dos saberes, entendendo-os como elementos de um dispositivo cuja natureza é estratégica. Assim, se a arqueologia tem como objetivo descrever as regras que regem as práticas discursivas que produzem sujeitos por meio dos saberes, a genealogia do poder propõe diagnosticar e compreender a racionalidade das práticas sociais que nos subjetivaram pelos seus efeitos e nos objetivaram pelas suas tecnologias, e a genealogia da ética busca problematizar as práticas de si e os processos de subjetivação que ligam o sujeito à verdade. Esses três momentos do percurso arquegenealógico de Michel Foucault - situado entre os anos de 1960 a 1984 - são atravessados e sustentados por uma teoria do discurso.

\section{Michel Foucault e os dispositivos de poder e saber}

Analisar as práticas discursivas para além de sua capacidade de designação e de referenciação significa, na proposta foucaultiana, reconhecer as articulações que os discursos estabelecem com os poderes na produção de verdades historicamente delimitadas. Significa, portanto, que o laço entre discurso e poder é inextricável e que a análise arquegenealógica deve enxergar as articulações que se estabelecem entre eles:

Meu objetivo é examinar as diferentes maneiras pelas quais o discurso cumpre uma função dentro de um sistema estratégico onde o poder está implicado e pelo qual funciona. O poder não está, pois, fora do discurso. O poder é algo que funciona através do discurso, porque o discurso é, ele mesmo, um elemento em um dispositivo estratégico de relações de poder. (FOUCAULT, 2003, p. 253, grifos meus) 
Por ter-se ocupado das relações entre discursos, saberes e poderes, Foucault revolucionou as teorias clássicas do Estado, na medida em que introduziu, nas análises históricas, a ideia de que o poder pode ser considerado como instrumento analítico capaz de explicar a produção dos saberes, sua existência e suas transformações como peças de relações de poder em dispositivos políticos (MACHADO, 1999, p. X). Um importante aspecto dessa inovação teórica foi a historicização do poder, isto é, Foucault mostrou que o poder se modifica sob o impacto das transformações históricas. Assim pensando, nos aponta a possibilidade de observarmos três diferentes economias de poder que se superpõem nas sociedades ocidentais: a) uma contemporânea da emergência dos Estados monárquicos europeus no final do período medieval, voltada para o problema da soberania e da lei; b) outra, correspondente ao desenvolvimento de técnicas de biopoder que incidem sobre a vida das populações, ao longo dos séculos XVII e XVIII; e c) outra, ainda, propriamente moderna - a partir do século XIX quando a tecnologia biopolítica já está consolidada e se centra no exercício regulador da normalização social.

Em síntese, subjaz à arquegenealogia foucaultiana o objetivo de diagnosticar e compreender a racionalidade de práticas sociais do saber e do poder que produziram o que somos nós, no nosso presente. Nesse contexto, principalmente pela necessidade de incorporar às análises a dimensão heterogênea das práticas discursivas e não discursivas que produzem subjetividades, Foucault elaborou o conceito de dispositivo. Se ele já estava latente nas análises arqueológicas, a partir dos anos 1970, Foucault insistirá, cada vez mais, na importância dos dispositivos. É interessante notar que não há, em seus livros, sistematização ou definição desse termo. As intervenções sobre esse conceito aparecem com regularidade em entrevistas e falas de Foucault ${ }^{1}$. O desenvolvimento desse conceito imprimiu novidades ao mesmo tempo teóricas, metodológicas e políticas às discussões clássicas sobre o poder: isso se deve, principalmente, pelo fato de que na base da ação dos dispositivos não se encontram a repressão ou a ideologia - como propõe a teoria marxista althusseriana, por exemplo - mas a normalização e a disciplina.

Um dos principais momentos em que Foucault se refere ao conceito encontra-se na entrevista "Sobre a história da sexualidade" (1999, p. 243-276) quando, interpelado sobre o sentido e a função metodológica dos dispositivos, aponta três facetas que ele imprime à noção. Em primeiro lugar, afirma que, com esse termo, tentou demarcar um conjunto heterogêneo "que engloba discursos, instituições, organizações arquitetônicas, decisões regulamentares, leis, medidas administrativas, enunciados científicos, proposições filosóficas, morais, filantrópicas". Resumindo, essa heterogeneidade demonstra que o dito e o não dito são elementos do dispositivo e ele próprio é "a rede que se pode estabelecer entre estes elementos" (FOUCAULT, 1999, p. 244). Em segundo lugar, Foucault demarca a natureza da relação que pode existir entre esses elementos heterogêneos, enfatizando que há sempre um certo tipo de jogo entre eles, ou seja, mudanças de posição, modificações de funções etc. Finalmente, em terceiro lugar, Foucault mostra que o dispositivo é um tipo de formação que, em um determinado momento histórico, teve como função principal responder a uma urgência. Por isso, ele tem uma função estratégica dominante que é determinada por um imperativo histórico.

Mais adiante, nessa mesma entrevista Foucault (1999, p. 146) acrescenta:

\footnotetext{
${ }^{1}$ Para Deleuze (1996) as mudanças teóricas que Foucault imprimia, naquele momento, em suas pesquisas, exigiam um outro modo de expressão, diferente daquele peculiar aos grandes livros.
} 
O dispositivo, portanto, está sempre inscrito em um jogo de poder, estando sempre, no entanto, ligado a uma ou a configurações de saber que dele nascem, mas que igualmente o condicionam. É isto, o dispositivo: estratégias de relações de força sustentando tipos de saber e sendo sustentadas por eles.

A emergência do conceito de dispositivo deriva do seu estudo sobre a história da sexualidade. Para Foucault, a "sexualidade" não é um dado da natureza, mas o nome de um dispositivo histórico, datado da metade do século XVIII: o dispositivo da sexualidade. Trata-se de uma rede composta por um conjunto de práticas, discursos e técnicas de estimulação dos corpos e de formação de conhecimentos. Quanto ao aspecto estratégico desse dispositivo, ele respondeu a uma urgência política da burguesia, de sua necessidade de afirmação que a levou a instituir seu corpo como fonte de inquietação e cuidado. Se anteriormente a nobreza se distinguia pelo "sangue", a burguesia marcou sua diferença e hegemonia atribuindo-se um corpo específico com saúde e higiene. A valorização de seus prazeres e a proteção de seu corpo contra perigos e contatos, além de garantirem seu vigor, descendência e longevidade, serviam como emblema de respeito e poder social. Afinal, diz Foucault, sua supremacia, além de depender da exploração econômica, requeria uma dominação física, já que "uma das formas primordiais da consciência de classe é a afirmação do corpo" e, por isso, a burguesia "converteu o sangue azul dos nobres em um organismo são e uma sexualidade sadia" (FOUCAULT, 1985, p. 119). Vemos, portanto, um exemplo de que um dispositivo tem sempre uma função estratégica concreta e se inscreve sempre em uma relação de poder.

Devido à sua força heurística e seu potencial para as análises históricas, Deleuze (1996) considera que a noção de dispositivo pode funcionar como um conceito operatório multilinear, alicerçado em três grandes eixos que se referem às três dimensões que Foucault distingue sucessivamente ao longo de sua obra: saber, poder e (produção de) subjetividades, entendidas como cadeias de variáveis relacionadas entre si:

Os objetos visíveis, os enunciados formuláveis, as forças em exercício, os sujeitos numa determinada posição, são como que vectores ou tensores. Por isso, as três grandes instâncias que Foucault vai sucessivamente distinguir, Saber, Poder e Subjectividade, não possuem contornos definidos de uma vez por todas; são antes cadeias de variáveis que se destacam uma das outras. (DELEUZE, 1996, p. 85)

Para Deleuze (op. cit, p. 87) o conceito foucaultiano de dispositivo se compõe de quatro dimensões articuladas: as curvas de visibilidade, as curvas de enunciação, as linhas de força e as linhas de subjetivação.

As primeiras duas dimensões dizem respeito às formas de funcionamento da enunciabilidade e da visibilidade que regem os elementos de um dispositivo. Trata-se, portanto, da forma como, em um determinado dispositivo, funcionam os seus "regimes de luz" e "regimes de enunciados", a maneira como se estabelecem jogos entre o visível e o invisível, a eloquência e o silêncio, com suas derivações, suas transformações, suas mutações. Já as linhas de força atuam como "flechas que não cessam de penetrar as coisas e as palavras". Elas estão intimamente relacionadas com a dimensão do poder e, por isso, atingem todos espaços do dispositivo, naquilo que o poder tem de "onipresente" - não no sentido de agrupar tudo numa (equivocada) unidade, mas em sua característica primeira de se produzir a cada momento, a partir da complexa e estratégica 
relação entre todos os pontos de um dispositivo. Quanto às linhas de subjetivação, são um processo, uma produção de subjetividade derivada das outras dimensões do dispositivo. Sendo um efeito que deriva das relações entre as outras dimensões, Deleuze considera a subjetivação como uma linha de fuga, produto de processos sempre mutáveis de acordo com as mudanças históricas.

Entrelaçando o saber, o poder e a subjetividade, o conceito de dispositivo sintetiza e reúne as grandes categorias que sustentam a analítica foucaultiana. Considerando esse poder de síntese, Courtine (2013, p. 79) propõe que se reinterprete o conceito de "formação discursiva", fundamental na arqueologia foucaultiana, a partir da complexidade da heterogeneidade histórica do conceito de dispositivo. Dessa maneira, segundo o autor, passa-se a entendê-la não somente como palavras, mas igualmente coisas, e os olhares que as captam, ou como o diz Deleuze, 'páginas de visibilidade' e 'campos de legibilidade'. Assim entendida, a formação discursiva pode aproximar-se do conceito de dispositivo, englobando linguagem (verbal e não verbal) e práticas. A análise de discursos teria como objetivo, então, o de reconstruir,

[...] a partir de rastros de linguagens, os dispositivos dos quais os textos não são senão uma das formas de existência material [...] tratase também de reconstruir práticas, de devolver vida aos gestos e carne aos corpos" (COURTINE, 2013, p. 57).

Acatando essa proposta de Courtine, propomos pensar a rede escolar instalada no Brasil no final do século XIX e início do século XX como um dispositivo constituído em um momento histórico determinado e que expressa, em seus enunciados, suas visibilidades, suas linhas de força e nas subjetividades dele derivadas, a urgência política de constituição da identidade brasileira logo após a proclamação da República. Para entender o funcionamento desse dispositivo, analisaremos fotografias coligidas em dois álbuns fotográficos da Escola Normal Caetano de Campos (São Paulo, SP) produzidos respectivamente em 1895 e em 1908. Nosso objetivo é evidenciar o funcionamento dos elementos desse dispositivo como estratégia para a produção e reprodução do ideário republicano.

\section{A instalação do dispositivo escolar e a memória fotográfica}

O cenário brasileiro no final do século XIX e meados do século XX estava convulsionado por grandes transformações que abrangiam um largo escopo: o campo da política (fim da monarquia e implantação da República); o da reorganização do trabalho (abolição dos escravos e chegada de trabalhadores europeus); o do reordenamento dos espaços urbano / rural e a remodelação das cidades; e o da economia (auge da cultura do café no sul e sudeste e o ciclo da borracha no norte). Era, portanto, um movimento amplo de transformações que atingiu profundamente as relações sociais e o cotidiano dos brasileiros:

Foram mudanças impactantes estimuladas, principalmente, por um novo dinamismo no contexto da economia internacional, as quais alteraram a ordem e as hierarquias sociais, as noções de espaço e tempo dos indivíduos e os modos de percepção do cotidiano. Nos planos culturais e econômicos, as transformações foram significativas: rupturas com alguns costumes coloniais, adoção de discursos científicos, abolição da escravatura, queda da monarquia, início de uma economia urbana e industrial, além da organização de um sistema educacional de âmbito nacional e incorporação de tecnologias (vacinas, soros, entre outras), com impacto nas ações de saúde desenvolvidas em território brasileiro. (SEVCENKO, 1998, p. 15) 
Essa amplitude das transformações foi impulsionada pelo apoio que a proclamação da República obteve tanto da intelectualidade progressista quanto da simpatia popular. Assim, apesar de não ter sido um movimento de massa, a República encontrou, em seus primeiros anos, ambiente propício para implantar mudanças que afetaram todos os estratos da nação. Essas mudanças eram guiadas pelo ideário republicano e tinham em sua base a plataforma política de que o progresso e a constituição da nação brasileira deveriam estar assentados estratégias a serem fortemente consolidadas: a higienização e a educação. As reformas políticas e sociais deveriam estar articuladas à reforma da educação.

A educação era colocada, assim, no centro do movimento de renovação das estruturas sociais do Brasil, com um modelo de escola elementar pensado para a escolarização em massa. Evidentemente, não se tratava de incorporar todas as classes e grupos sociais já que a estrutura escolar e seus conteúdos seguiam o modelo das elites econômicas. Mais do que oferecer educação para todos, o objetivo da reforma republicana era oferecer ensino a alguns segmentos que vinham reivindicando instrução pública. Assim, o projeto educacional republicano era sustentado pela ideia de que esse tipo de educação seria o esteio para o desenvolvimento nacional:

\begin{abstract}
A educação pelo voto e pela escola foi instituída por eles como a grande arma da transformação evolutiva da sociedade brasileira, e assim oferecendo em caução do progresso prometido pelo regime republicano: a prática do voto pelos alfabetizados e, portanto, a frequência à escola que formaria o homem progressista adequado aos tempos modernos, é que tornaria os súditos em cidadão ativo (HILSDORF, 2005, p. 60).
\end{abstract}

Trata-se, portanto, de um momento histórico em que se apresentava como necessário ultrapassar as estruturas arcaicas estabelecidas pela monarquia e a via mais rápida seria o desenvolvimento e nacionalização da educação, com vistas à diminuição do analfabetismo. Um dos pilares da implantação do dispositivo escolar fundamentou-se na elaboração de enunciados que ligaram as práticas de linguagem à nossa nacionalidade. Nesse sentido, promoveu-se o reordenamento das práticas pedagógicas, incluindo a preocupação com a escrita e, consequentemente, o surgimento de cartilhas que buscavam introduzir e ampliar o ensino de uma escrita mais homogênea e regular em todo o país. A República nacionalizou o ensino da língua materna (e de geografia e história) e, para isso, houve necessidade de nacionalizar o livro didático. Com o passar dos anos, eles foram incorporados de forma tão sólida à memória escolar coletiva brasileira que acabaram por constituírem-se em importantes instrumentos para a consolidação da ideologia republicana. Várias gerações se imbuíram, por meio dessas leituras escolares, das representações do Brasil como pátria moderna e civilizada, a exemplo das Poesias Infantis (Olavo Bilac, 1904) e os Contos Pátrios (Coelho Netto e Olavo Bilac, 1911).

Ademais dessas enunciabilidades, os ideais republicanos foram materializados na implantação do dispositivo escolar sob a forma de uma rede de prédios como objetos visíveis que abrigaram enunciados formuláveis, expressando forças em disputa para a produção de subjetividades. Visibilidade, enunciabilidade, linhas de força e processos de subjetivação: eis os vetores ou tensores desse dispositivo que expressava os valores do progresso e da modernidade de um "novo Brasil". 
Com relação às curvas de visibilidade e de enunciabilidade - que são, para Foucault, os primeiros elementos de um dispositivo - o ensino público foi dotado, primeiramente, de uma estrutura arquitetônica escolar específica, que seguia os preceitos do estilo "moderno", cujos padrões arquiteturais, em São Paulo, era ditado por mestres, operários e artistas geralmente imigrantes, das oficinas-escolas do Liceu de Artes e Ofícios. Essa estrutura arquitetônica escolar tinha como característica principal a racionalização dos espaços, seus usos e funções, bem como a normatização de plantas e fachadas. Dotada dessa visibilidade específica, a escola passava a ser reconhecida na paisagem urbana como um espaço arquitetônico definido.

A implantação do dispositivo escolar foi um esforço nacional para a construção de uma identidade republicana para o nosso país. Como resultado desse esforço, nas duas primeiras décadas do regime republicano, edifícios escolares obedecendo às regras dessa estrutura arquitetônica moderna foram instalados em muitas capitais do Brasil: nos estados de São Paulo (1894); Rio de Janeiro (1897); Pará (1901); Maranhão e Paraná (1903); Minas Gerais (1906); Bahia, Rio Grande do Norte, Espírito Santo e Santa Catarina (1908); Mato Grosso (1910); Sergipe (1911); Paraíba (1916) e Piauí (1922). (VIDAL, 2006, p. 7). A regularidade das fachadas e dos lugares da paisagem urbana em que foram implantados denota a face mais concreta das curvas de visibilidade desse dispositivo, conforme podemos visualizar nas Figuras 1 e 2 a seguir:

Figura 01 - Escola Normal Caetano de Campos (São Paulo, 1894).

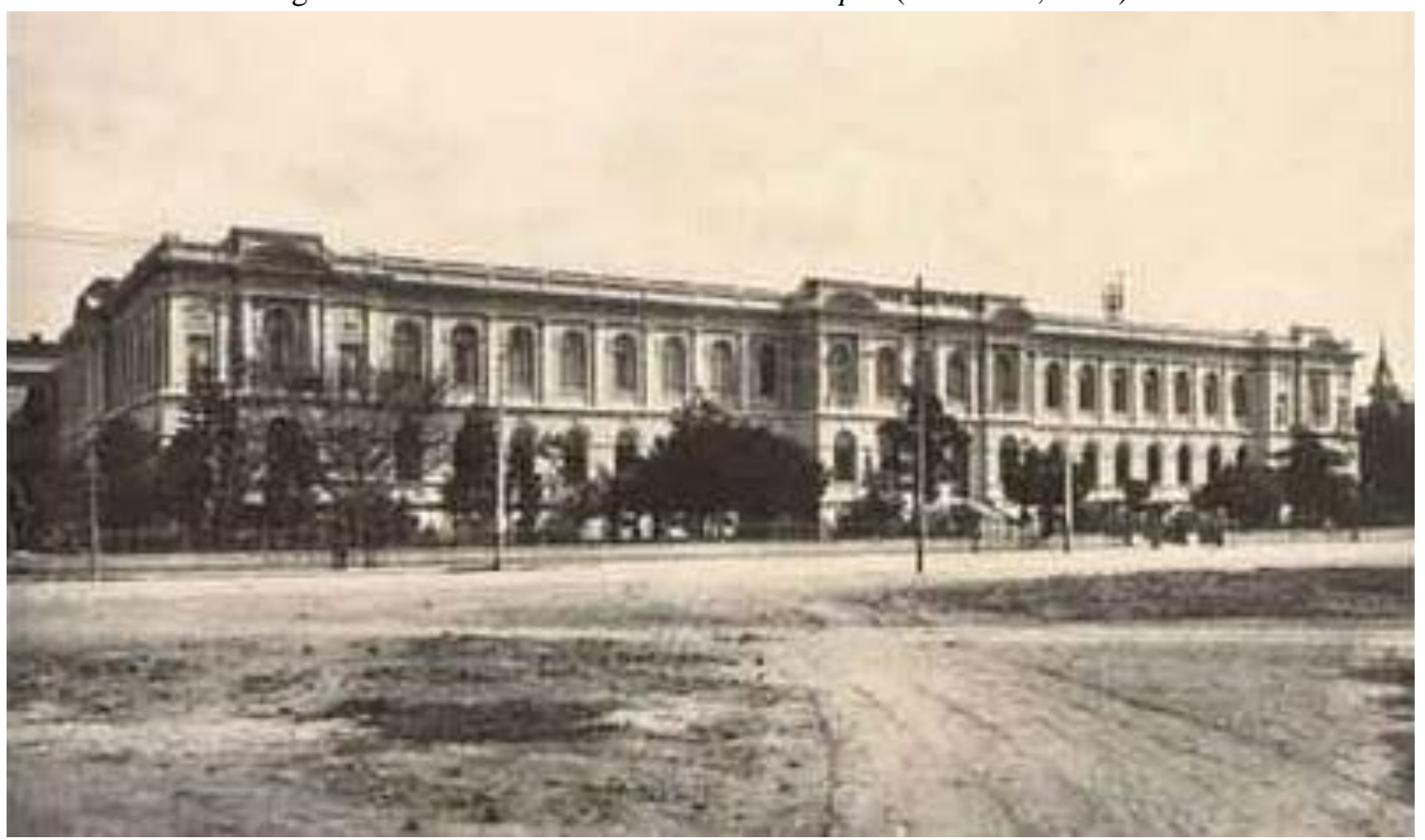

Fonte: Album Photographico da Escola Normal - 1895 


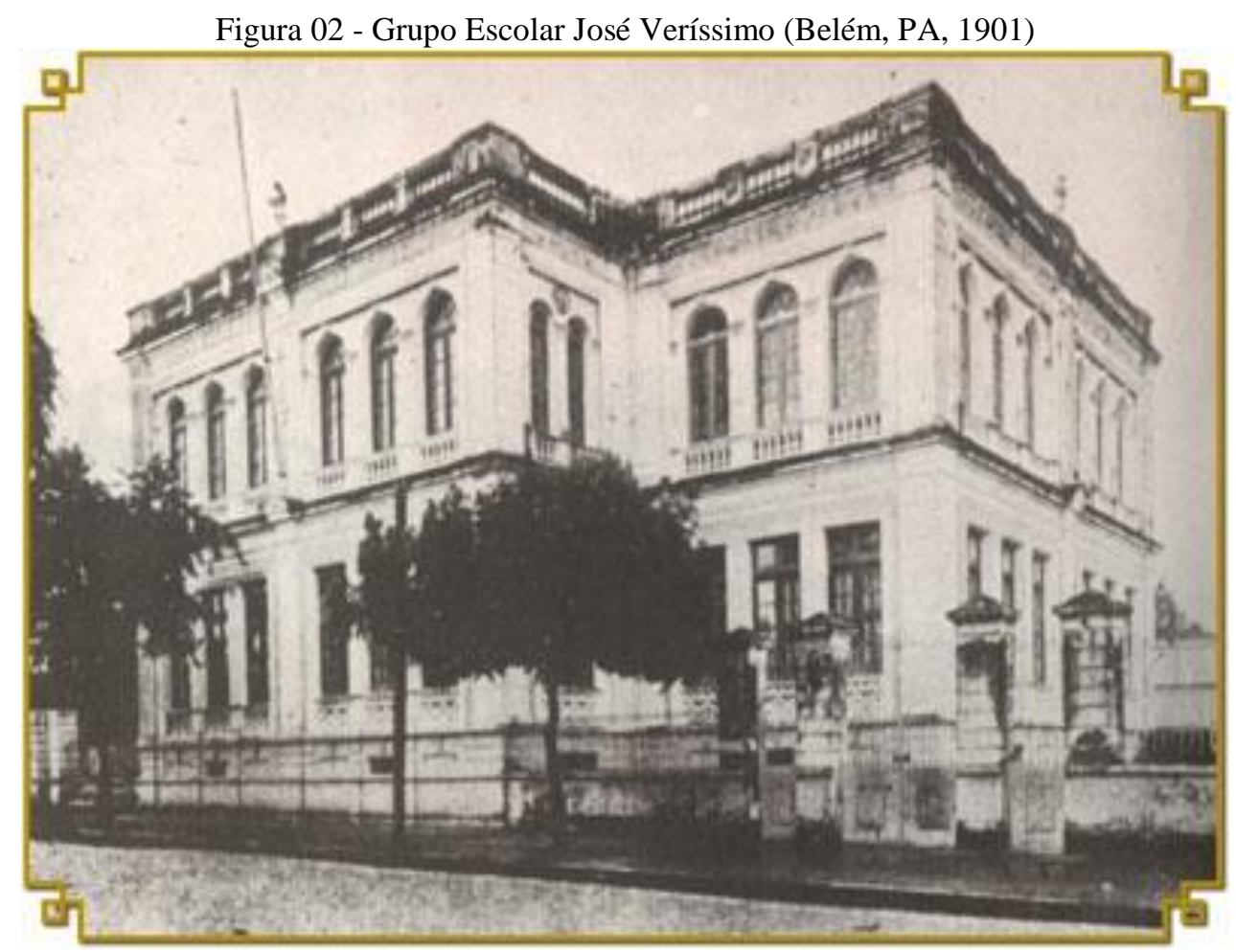

Fonte: A Educação no Pará, documentário. Belém-PA: Ed. Bel-Graff, 1987

A suntuosidade dos prédios, a localização em vias de grande movimento, geralmente de topografia elevada são alguns dos predicados que constituíram o lugar da escola na remodelação urbana e produziram, pela excessiva visibilidade, a marca indelével do progresso em curso pelas mãos republicanas.

Entretanto, essa visibilidade teria ainda um aliado fortíssimo que deveria garantir-lhe perenidade. Por isso, uma outra forma de visibilidade foi produzida a fim de assegurar a permanência, a remanência dessa Escola na memória coletiva: a imagem fotográfica. Esse gesto de inscrever a escola em uma materialidade fotográfica deriva do fato de que a implantação do dispositivo escolar republicano coincidiu com um momento em que a fotografia começava a se popularizar devido aos avanços técnicos que ampliavam o seu uso social: a invenção da câmera portátil (1881) e, principalmente, o desenvolvimento de um novo sistema de reprodução fotomecânica que permitia a impressão de fotos em publicações e cartões postais, superando a litografia e dando origem ao fotojornalismo (VIDAL, 1998).

A Figura 3 exemplifica o uso da fotografia em cartão postal. Trata-se de imagem que pertence à série de postais Lembrança de São Paulo, do fotógrafo Guilherme Gaensly, realizada entre os anos de 1900 a 1910: 
Figura 03 - Cartão postal com vista da Praça da República e a Escola Normal (Caetano de Campos)

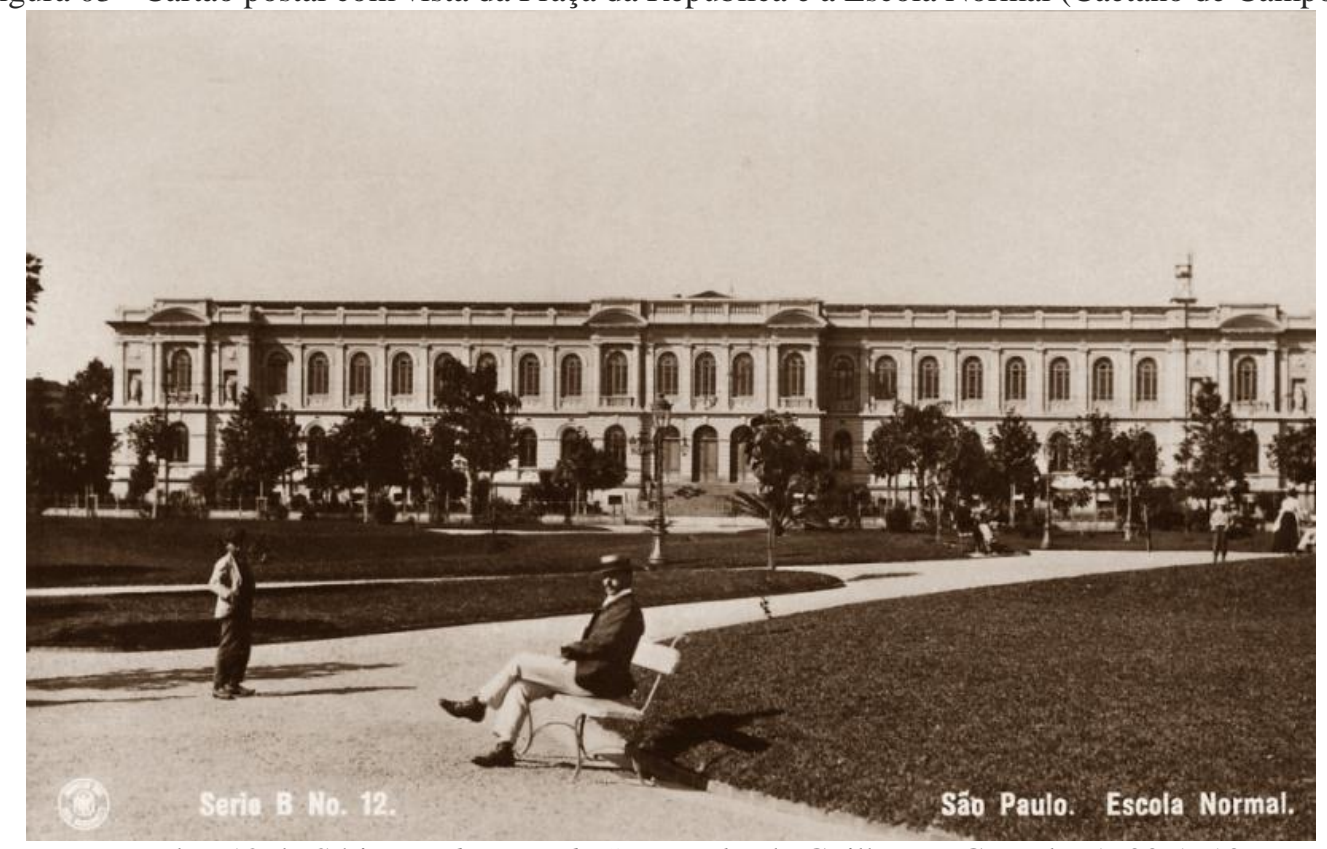

Postal n. 12 da Série Lembrança de São Paulo, de Guilherme Gaensly, 1900-1910

O fotógrafo G. Gaensly (1843-1928) é considerado um dos maiores responsáveis pela memória iconográfica da belle époque de São Paulo do início do século XX. Sua lente captou e fixou casarões, edifícios, espaços públicos e deu materialidade, principalmente, à remodelação da cidade que lhe imprimia ares europeus de grande metrópole $^{2}$. O postal apresentado na Figura 3 mostra que entre os signos de modernidade captados pela lente de Gaensly figura a imagem imponente da Escola Normal (Caetano de Campos), na Praça da República, atestando o valor que ela representa como símbolo do progresso do país.

Essa relevância da Escola Normal, depois denominada Escola Caetano de Campos (e popularmente conhecida como "Escola da Praça") tem vários motivos históricos. Inaugurada em 1894, foi o primeiro prédio da rede escolar republicana e, portanto, inaugurou a visibilidade do dispositivo escolar a ser implantado no Brasil. Sua arquitetura monumental serviu de parâmetro para a arquitetura escolar a ser imprimida em outras escolas construídas no período, reforçando em suas linhas o sentido de que havia naquele governo uma vontade de verdade: a do desenvolvimento da educação brasileira. Originalmente, o prédio abrigava a Escola Normal destinada à formação de professores primários e uma Escola Modelo Anexa para as séries iniciais e objetivava desenvolver métodos a serem padronizados e aplicados nos Grupos Escolares que estavam sendo instalados no interior do estado de São Paulo. Em 1896 ela sofreu sua primeira ampliação, com a inauguração do Jardim da Infância ${ }^{3}$.

Os sentidos de modernidade, progresso, democracia, qualidade etc. atribuídos à Escola Caetano de Campos foram produzidos não só pela lente de fotógrafos, como Gaensly, interessados em mostrar as paisagens da cidade em mutação, na marcha para o progresso. Ela própria, enquanto instituição, produziu uma espécie de "escrita de sua história" fixando uma memória fotográfica em álbuns e fotografias avulsas que

\footnotetext{
2 A obra de Gaensly pode ser admirada no livro que leva seu nome, publicado em 2011 pela Editora Cosac Naif.

${ }^{3}$ Outras informações disponíveis em: http://www.iecc.com.br. Acesso em 10/12/2013.
} 
atualmente constituem o seu acervo iconográfico ${ }^{4}$. Interessam-nos, neste artigo, dois desses álbuns, produzidos nos primeiros anos da Escola Normal:

a) Álbum Photographico da Escola Normal - 1895 (36 páginas, caixa 1 AECC) que registra a arquitetura do prédio escolar e suas instalações, em imagens nas quais não aparecem os sujeitos que os ocupam. Professores e alunos figuram no álbum em fotografias separadas dos espaços da escola:

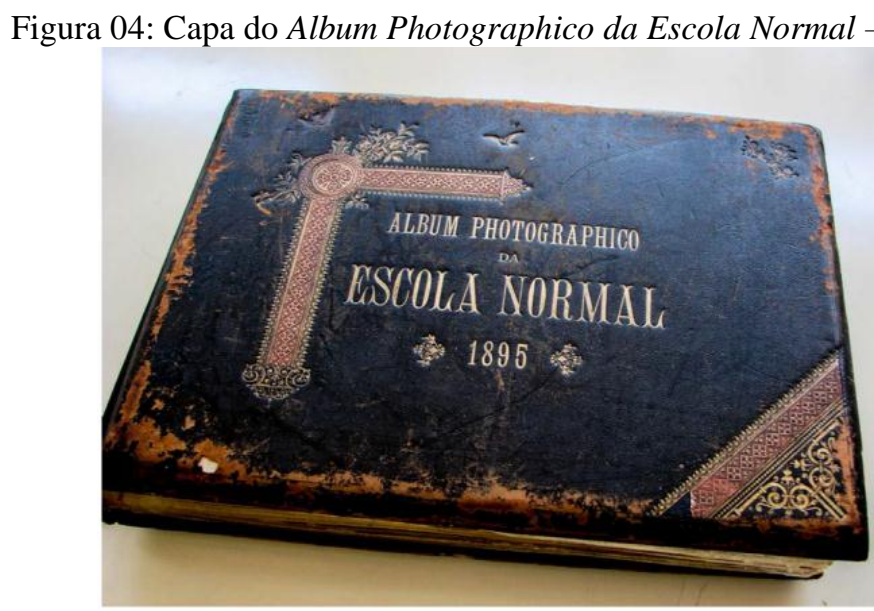

Fonte: ABDALA, 2013, p. 64

b) Album de Photographias da Escola Normal e Annexas de São Paulo -1908 (83 páginas, caixa 2 AECC), registra práticas escolares e situações de ensino nas quais estão inseridos professores e alunos. Não há, assim, separação entre espaços, seus usos e os sujeitos que os habitam:

Figura 05: Capa do Album de Photographias da Escola Normal e Annexas de São Paulo -1908

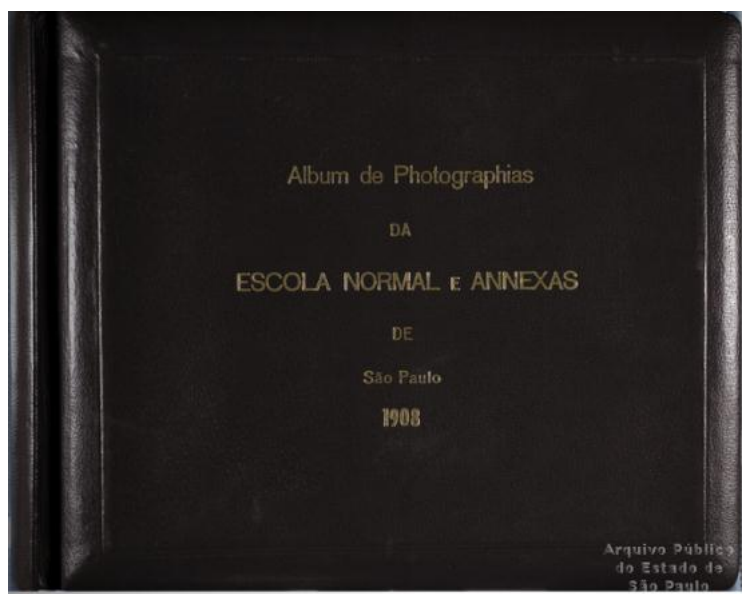

Fonte: Arquivo Público do Estado de São Paulo

\footnotetext{
${ }^{4} \mathrm{O}$ acervo do Arquivo da Escola Caetano de Campos (AECC), compõe-se de 23 álbuns fotográficos que cobrem um período de quase cem anos, entre 1895-1966 e está sob a guarda do Centro de Memória em Educação (CRE) Mário Covas, em São Paulo, SP. Trabalho detalhado sobre esses álbuns encontra-se em ABDALA (2013).
} 
Esses dois álbuns, como os demais do AECC, tem como temática o prédio escolar e as atividades neles realizadas. Caracteriza esses dois álbuns o fato de que as imagens foram feitas por fotógrafos profissionais. São fotografias posadas que impõem uma certa ordem do olhar, dispondo os elementos em uma regularidade que busca controlar os sentidos (como veremos mais à frente, na imagem da saída das meninas); mas sempre algo do sentido escapa ao controle (por exemplo, as diferenças entre as aulas de ginástica de meninos e de meninas). São fotografias que guardam vestígios e representações de práticas que habitaram a instituição escolar (FABRIS, 1991). Certamente, os álbuns foram encomendados para produzir memória por meio da visibilidade e da enunciabilidade; o que se mostra diz muito sobre a representação que se quer produzir por meio da série fotográfica: um modelo de excelência a ser seguido pela escola republicana.

\section{Corpos e espaços: linhas de força e processos de subjetivação}

As imagens dos espaços da Escola Caetano de Campos, que predominam no Álbum de 1895, detalham aspectos de sua fachada e do seu interior e produzem, pela perspectiva e simetria dos elementos, os sentidos de ordem, organização, amplitude, funcionalidade:

Figura 06: Vista dos corredores internos da Escola. Album Photographico da Escola Normal - 1895

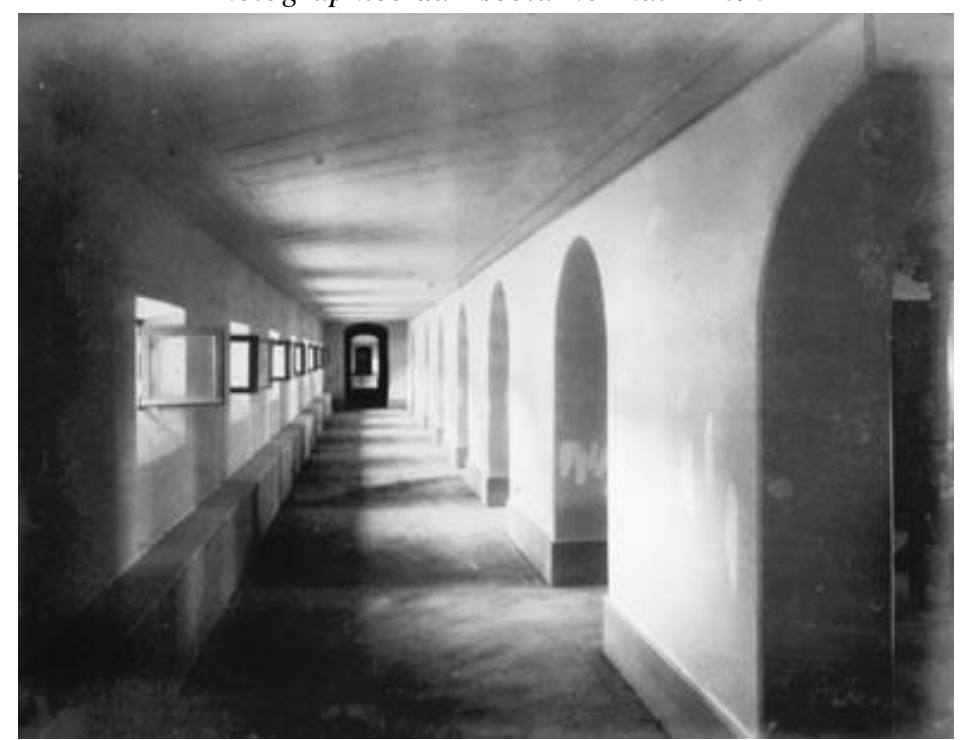

Fonte: Acervo da Escola Caetano de Campos/CRE Mario Covas.

A vista dos corredores, apresentada na Figura 6, exemplifica a materialidade desses sentidos. Nosso olhar é levado a percorrer a extensão do corredor, a perscrutá-lo e perceber que nele é possível controlar os corpos, por meio do controle do espaço. É, portanto, a imagem do interior de um desses edifícios de que nos fala Foucault em Vigiar e Punir (1991): prédios sólidos (prisões, fábricas, hospitais, escolas ...) em cujos interiores o saber é produzido pela vigilância. A reflexão de Foucault sobre as articulações entre corpos e espaços se dá no âmbito da discussão sobre o funcionamento do poder disciplinar, característico da sociedade biopolítica que se desenvolveu a partir 
do século XIX. Essa sociedade da disciplina construiu uma maquinaria de poder através do controle dos corpos (anatomia política), que se desenha aos poucos até alcançar um método geral e espalhar-se numa microfísica do poder que vem evoluindo em técnicas cada vez mais sutis, mais sofisticadas, tomando o corpo social em sua quase totalidade. A disciplina funciona por meio de procedimentos muito específicos, dentre os quais Foucault (1991) destaca:

a) o controle dos espaços por meio de regulamentos minuciosos, do olhar das inspeções e do controle sobre o corpo que tomam forma nas escolas, prisões, quartéis etc. Nessa microfísica do poder, a disposição dos corpos permite o olhar, isto é, a vigilância;

b) a organização do tempo, com o consequente controle e regulamentação sobre os ciclos da repetição;

c) a vigilância contínua, ininterrupta e, acima de tudo, vista pelos indivíduos que a ela estão expostos como perpétua e permanente;

d) a produção do saber e seu registro contínuo: o caderno de anotação, a ficha secreta, a prova, a correção etc. são materialidades que mostram o acúmulo do saber produzindo poder.

Segundo essas teses de Foucault, o poder está fundamentalmente ligado ao corpo, em todas as sociedades modernas, uma vez que é sobre ele que se impõem as obrigações, as limitações e as proibições. Ele mostra que, nos séculos XVII e XVIII, junto com a aparição da arte do corpo humano, houve a descoberta do corpo como objeto transformável em eficiência e alvo do controle. É o que ele denomina de "momento das disciplinas". Desde então, os mecanismos disciplinares que organizam os corpos nas prisões, nos hospícios, nos quartéis, nas empresas, nas escolas etc. tomam a forma social mais ampla de uma sofisticada e sutil tecnologia de submissão em movimentos, gestos e silêncios que orientam o cotidiano:

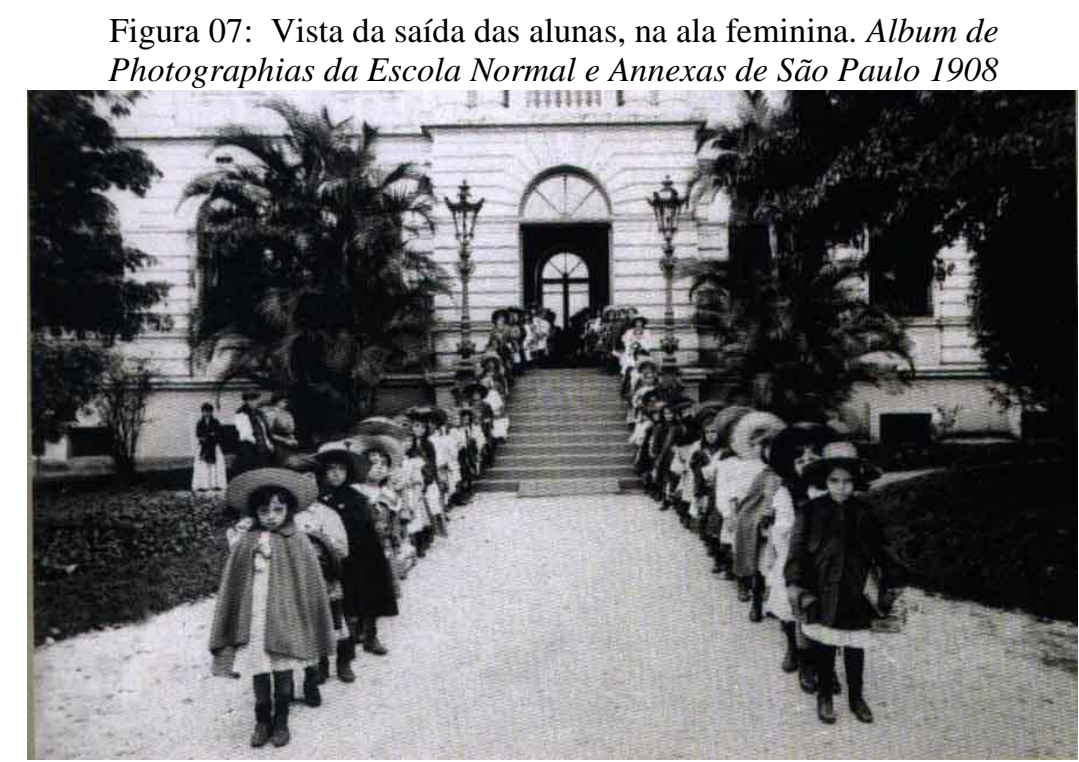

Fonte: Acervo da Escola Caetano de Campos/ CRE Mário Covas.

A vista da saída das alunas, na Figura 7, nos apresenta ao olhar a regularidade da disposição dos corpos infantis em duas filas simétricas que descem a escadaria da saída do prédio. Nessa imagem extremamente organizada, a pose materializa o olhar vigilante que, do interior das instituições ganha prolongamento social nas ações da vida cotidiana. Esse controle do olhar se funde com a disciplina organizadora do tempo e do 
espaço, criando o império da regularidade, do ritmo. Assim como na distribuição dos espaços, o controle sobre o tempo permanece introjetado na realização social da vida cotidiana e em todos os setores, inclusive na vida "pessoal e íntima". Entranhada no cotidiano, a vigilância aparece como algo que deve ser contínua, ininterrupta e que, acima de tudo, precisa ser vista, pelos indivíduos que a ela estão expostos, como perpétua, permanente; do mesmo modo, é preciso que ela não tenha limites, que esteja presente em toda a extensão do espaço. A vigilância é, pois, um olhar invisível, que deve impregnar quem é vigiado de tal modo que este adquira de si mesmo a visão de quem o olha. O poder sobre os corpos, desta forma, atinge o ápice da submissão, pois o corpo não distingue entre si mesmo e o olho do poder.

Funcionando junto com outras formas sutis de controle dos corpos, essas técnicas disciplinares (sobre o espaço, o tempo, a vigilância e o saber) se desenvolvem em quase todas as instituições, a partir do século XIX, e seu propósito é produzir "o sujeito individual obediente aos hábitos, regras, ordens; uma autoridade que é exercida continuamente em volta e acima dele e que ele deve internalizar para funcionar automaticamente nele" (FOUCAULT, 1991, p. 227).

Essas práticas disciplinares são concretizadas, nas imagens fotográficas da Escola Caetano de Campos, em várias outras situações como, por exemplo, no grande número de vistas das aulas de educação física. Conforme já afirmamos, as duas âncoras da renovação do país impressas pelos republicanos eram a saúde e a educação. Nas salas de aula, carteiras importadas da Europa e Estados Unidos mantinham o corpo dos alunos na posição correta, prevenindo a escoliose, como era recomendado nos discursos médicos da época. Os cuidados com a saúde levaram à inclusão da ginástica e dos esportes nos currículos escolares. Dentro desse espírito, era preciso cultivar a educação física a fim de obter, pelo controle do corpo, o controle intelectual e moral. Dentre as várias imagens do Album de 1908, destacamos as duas apresentadas a seguir:

Figura 08: Aula de ginástica da ala feminina. Album de Photographias da Escola Normal e Annexas de São Paulo - 1908

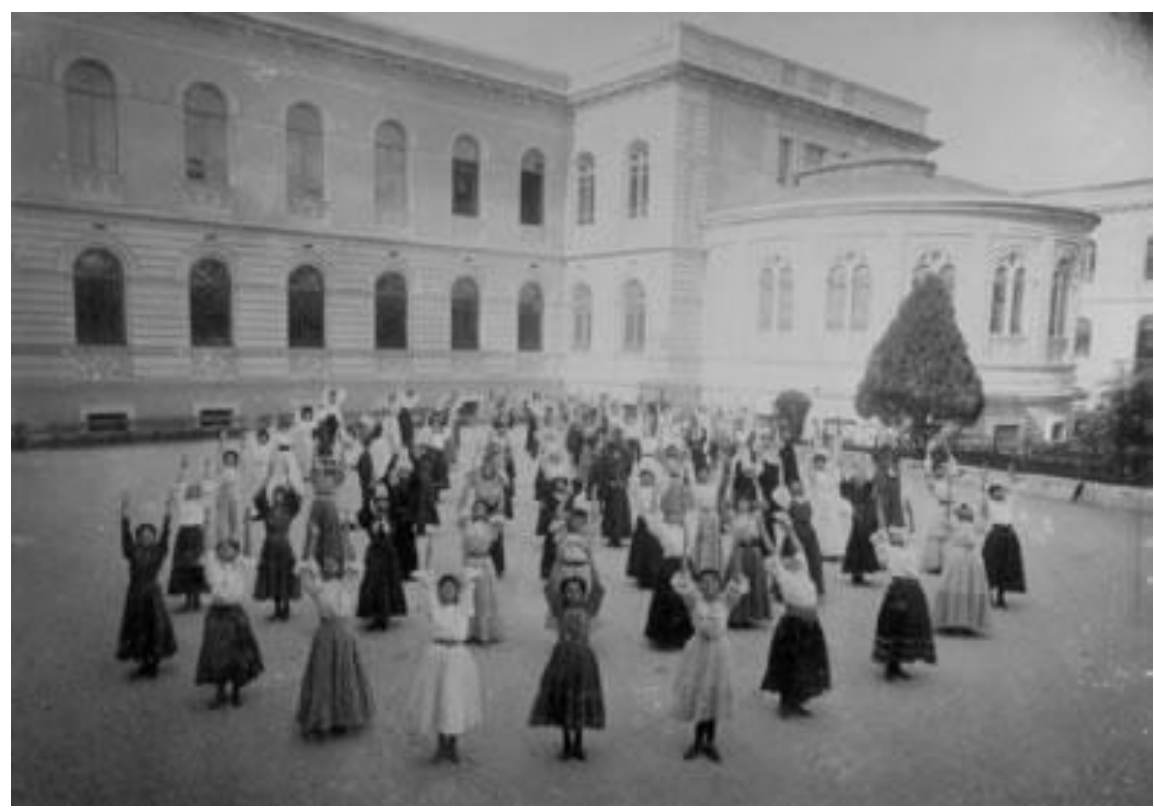

Fonte: Acervo da Escola Caetano de Campos/CRE Mário Covas

Figura 09: Aula de exercícios militares da ala masculina. Álbum de Photographias da Escola Normal e Annexas de São Paulo - 1908 


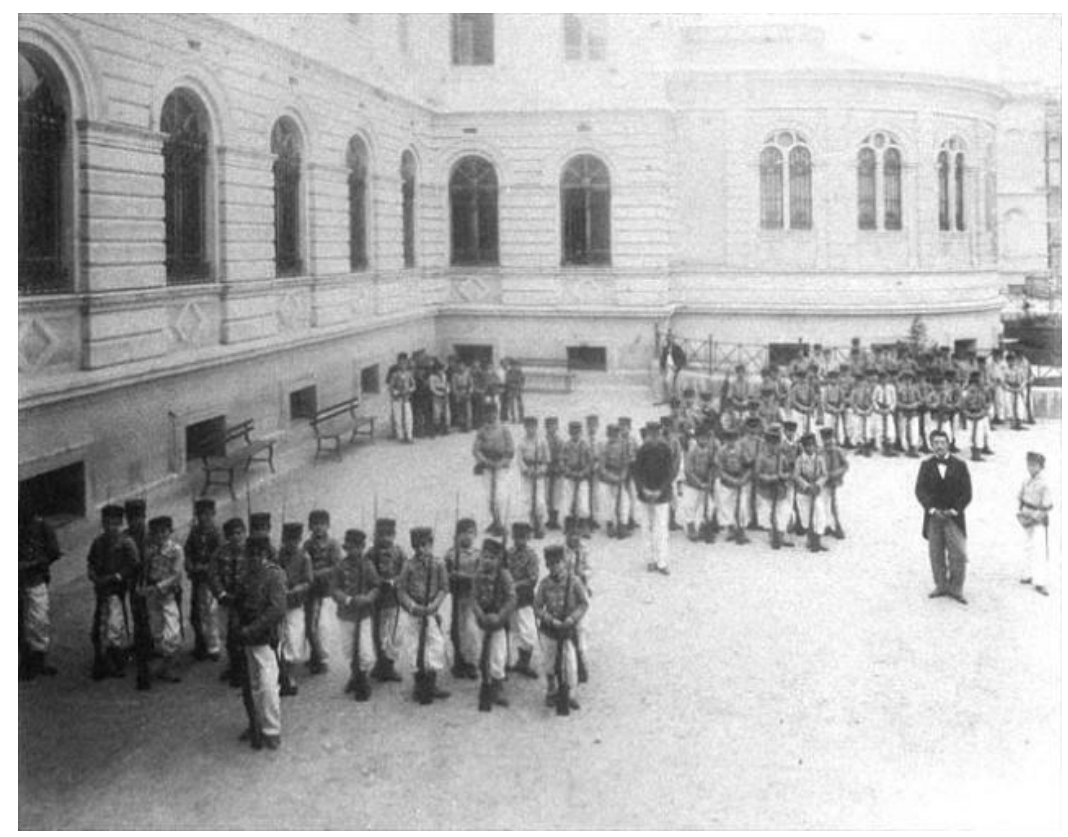

Fonte: Acervo da Escola Caetano de Campos/CRE Mário Covas

A separação do espaço da escola em duas alas independentes e com entradas próprias inscreve no espaço a divisão de gênero e seus lugares sociais. Assim, apesar de, pela primeira vez a escola ter incluído as mulheres como alunas e, portanto, iniciar-se o seu processo escolar de educação, a divisão de tarefas e atividades masculinas e femininas reproduz e reafirma a "fragilidade" e a "domesticalidade" das meninas e, ao mesmo tempo, a "militarização" dos meninos. Essa divisão era expressa também nas matérias escolares direcionadas diferentemente para homens e mulheres. Segundo o artigo 269 de 1892 das diretrizes pedagógicas, haveria um conjunto de disciplinas comuns a ambos os sexos, "exceto o de Agrimensura, Economia Política e Exercícios militares que é destinado exclusivamente aos homens e Economia doméstica às mulheres." Essa divisão de papéis expressa bem o que afirma Foucault sobre a função da educação na sociedade moderna:

\begin{abstract}
A educação pode muito bem ser, de direito, o instrumento graças ao qual todo o indivíduo, numa sociedade como a nossa, pode ter acesso a qualquer tipo de discurso; sabemos no entanto que, na sua distribuição, naquilo que permite e naquilo que impede, ela segue as linhas que são marcadas pelas distâncias, pelas oposições e pelas lutas sociais. Todo o sistema de educação é uma maneira política de manter ou de modificar a apropriação dos discursos, com os saberes e os poderes que estes trazem consigo (FOUCAULT, 2004, p. 12).
\end{abstract}

As imagens fotográficas das Figuras 8 e 9 evidenciam o funcionamento das linhas de força e a produção de subjetividades no interior do dispositivo escolar republicano.

\footnotetext{
${ }^{5}$ Disponível em: http://www.iecc.com.br. Acesso em 25 de janeiro de 2015.
} 


\section{O atual não é o que somos, mas aquilo em que nos vamos tornando}

Segundo Deleuze (1996) as diferentes linhas de um dispositivo repartem-se em dois grupos: linhas de estratificação ou de sedimentação e linhas de atualização ou de criatividade. As primeiras constituem elementos que se consolidaram e que caracterizam os dispositivos em um certo momento; os segundos são elementos em transformação, são processos em curso. Para Deleuze, Michel Foucault tratou obstinadamente, com rigor, os elementos de estratificação de vários dispositivos como o hospital no século XVII, a clínica no século XVIII, a prisão no século XIX, a subjetividade na Grécia Antiga e no cristianismo. A Figura 10, apresentada a seguir retrata vários elementos que podemos considerar com estratificações do dispositivo escolar e que incidem sobre a forma como os corpos ocupam o espaço da sala de aula. São práticas que se desenvolveram a partir do ideário republicano e que atravessam a história da Escola brasileira até nossos dias, nas atividades escolares:

Figura 10: Aula de leitura da ala masculina. Álbum de Photographias da Escola Normal e Annexas de São Paulo-1908

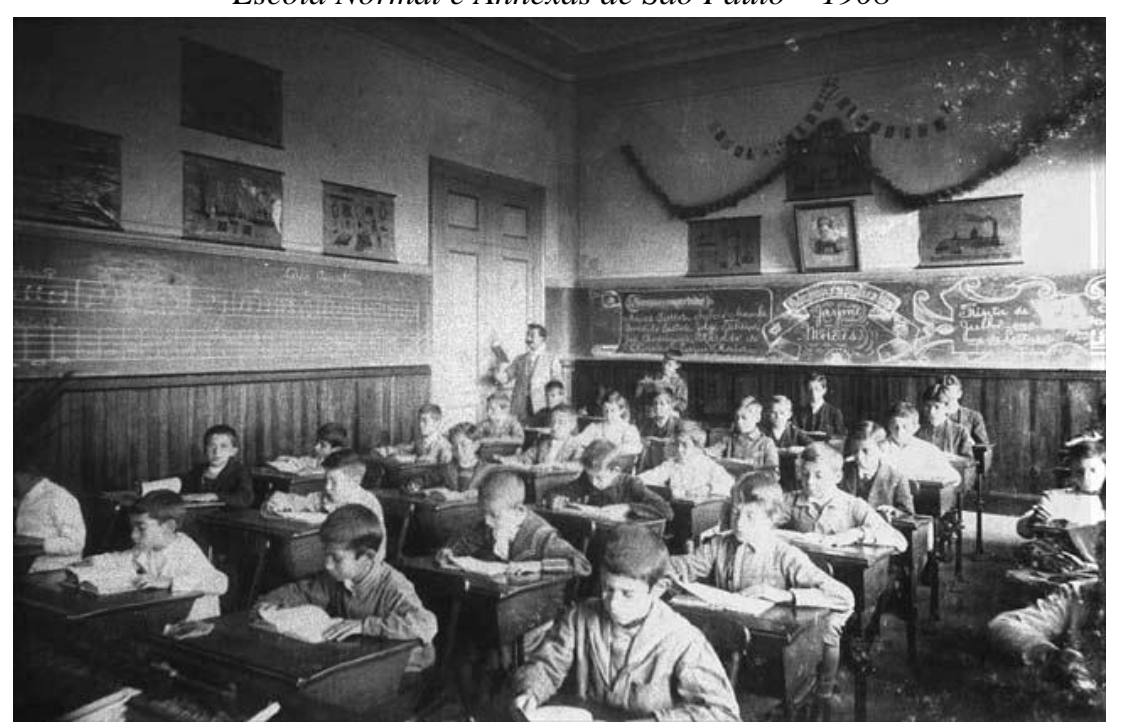

Fonte: Acervo da Escola Caetano de Campos/CRE Mário Covas

Entretanto, afirma Deleuze, Michel Foucault não teve tempo de formular as linhas de atualidade dos dispositivos, a não ser em algumas entrevistas, contemporâneas de cada um dos grandes livros; nelas se encontram questões como o que sucede hoje em dia com a loucura, com a prisão, com a sexualidade? que novos modos de subjetivação surgem hoje em dia, que nem são gregos nem cristãos?

Ao afirmar isso, Deleuze tem a intenção de mostrar que a sociedade disciplinar descrita por Michel Foucault já é algo que estamos deixando de ser pois a ela sucedeu uma nova forma de sociedade, a do controle. A sociedade disciplinar é aquela na qual o comando social é construído mediante uma rede difusa de dispositivos que regulam os costumes, os hábitos e as práticas produtivas e a disciplina é assegurada por meio de instituições instaladas em edifícios sólidos (prisão, fábrica, asilo, escolas...) que estruturam o terreno social e fornecem explicações lógicas adequadas para a "razão" das 
disciplinas. A escola republicana tratada neste artigo pode ser considerada como típica dessa sociedade disciplinar.

Já a sociedade do controle, segundo Deleuze (1992, p. 219-226) desenvolveu-se a partir dos anos 1950, quando os mecanismos de comando social tornaram-se cada vez mais "democráticos", cada vez mais imanentes ao campo social, distribuídos pelos corpos e cérebros dos cidadãos. $\mathrm{O}$ controle adquire a forma de uma vigilância geral exercitada sob uma variedade de formas, que vão desde as câmeras colocadas em cada canto dos prédios até as estatísticas e os sistemas de segurança que são usados para aferir e modelar o cotidiano. Nessa sociedade, o poder é cada vez mais exercido por máquinas que organizam diretamente o cérebro (em sistemas de comunicação, redes de informação etc.) e os corpos (em sistemas de bem-estar, atividades monitoradas etc.) no objetivo de um estado de alienação independente do sentido da vida e do desejo de criatividade. Há um sistema de normalização da disciplinaridade que anima internamente nossas práticas, capilarizado fora das instituições, mediante redes flexíveis e flutuantes. (HARDT; NEGRI, 2001, p. 41-60). Implantam-se novos tipos de sanção, de educação, de tratamento: hospitais abertos, atendimento a domicílio, educação a distância, formação continuada baseados no controle contínuo e na comunicação instantânea possibilitada pelas tecnologias digitais e pelo desenvolvimento do ambiente virtual. Para escapar ao controle, há a pirataria, os vírus disseminados pelos hackers. O marketing é um instrumento do controle social, contínuo e ilimitado. O animal da disciplina é a toupeira; a do controle é a serpente: "os anéis de uma serpente são ainda mais complicados que os buracos de uma toupeira" (DELEUZE, 1992b, p. 225).

Essa passagem de uma sociedade disciplinar a uma baseada no controle enseja o surgimento de outras visibilidades, outras enunciações, outras formas de poder, outras formas de subjetivação. A história é o arquivo, é o desenho do que somos e deixamos de ser, enquanto o atual é o esboço daquilo em que vamos nos tornando:

Figura 11: Página de abertura do Portal da Secretaria da Educação do Estado de Rondônia

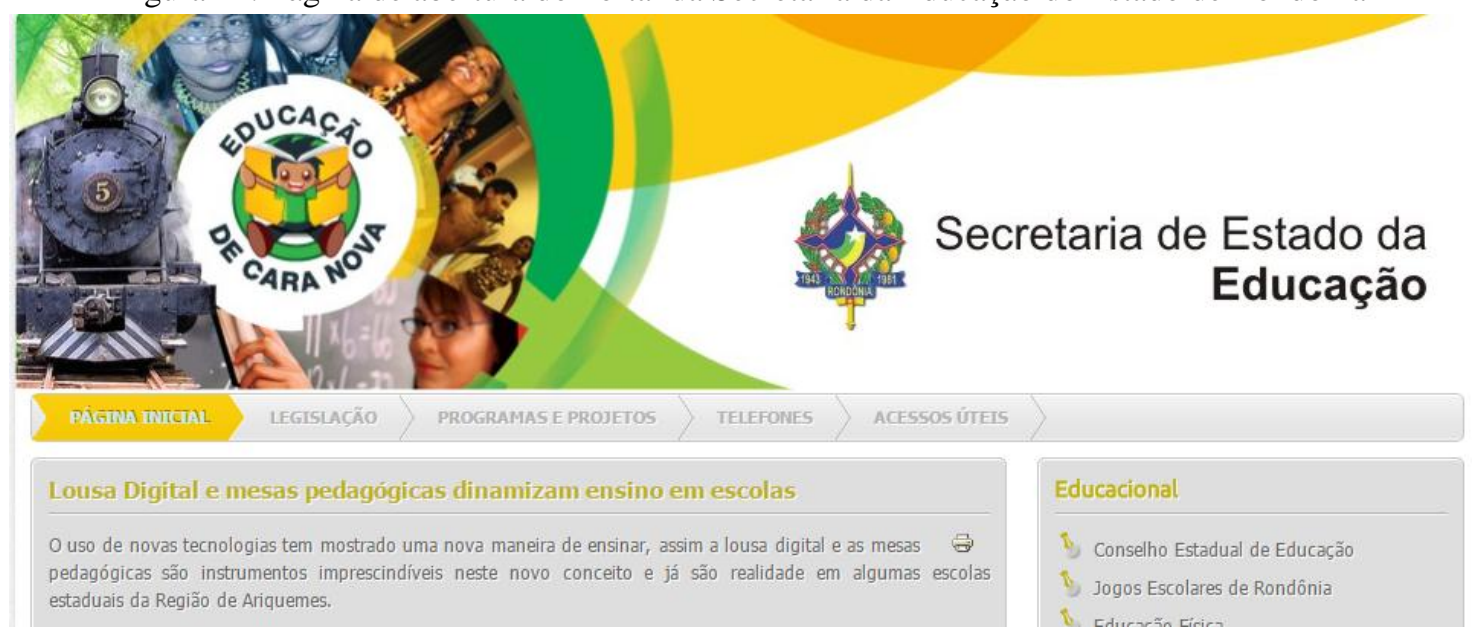

Disponível em: <http://www.seduc.ro.gov.br/portal>. Acesso em 25/01/1915.

Apenas a título de motivação para outras análises, a Figura 11 exemplifica a ideia de uma educação atual, "de cara nova". O novo são os dispositivos tecnológicos aplicados ao ensino - a lousa digital e as mesas pedagógicas. Resta entender as "novas" 
faces visíveis no alto da página onde se veem indígenas, a locomotiva da estrada Madeira-Mamoré (1907-1912) e outros signos da identidade construída, ao longo do século XX, para o estado de Rondônia. A subjetividade é processo em curso, por isso, a atualidade é sempre contraditória, tem sempre uma incompletude constituinte que nos impede de enxergá-la com inteireza:

Pertencemos a dispositivos e neles agimos. À novidade de um dispositivo em relação aos que o precedem chamamos atualidade do dispositivo. O novo é o atual. $\mathrm{O}$ atual não é o que somos, mas aquilo em que nos vamos tornando, aquilo que somos em devir, quer dizer, o Outro, o nosso devir-outro (DELEUZE, 1996, p.94).

\section{Referências bibliográficas}

ABDALA, R. D. Fotografias escolares: práticas do olhar e representações sociais nos álbuns fotográficos da Escola Caetano de Campos (1895-1966). Tese (Doutorado em Educação). Faculdade de Educação, Universidade de São Paulo, São Paulo, 2013.

COURTINE, J-J. Decifrar o corpo. Pensar com Foucault. Petrópolis/RJ: Vozes, 2013. DELEUZE, G. Um retrato de Foucault. In: Conversações 1972-1990. São Paulo: Ed. 34, 1992a, p. 127-147.

Post-Scriptum sobre as sociedades de controle. In: Conversações: 1972-1990.

Rio de Janeiro: Ed. 34, 1992b, p. 219-226.

O que é um dispositivo? In: O mistério de Ariana. Lisboa: Vega/Passagens, 1996, p. 83-96.

FABRIS, A (Org). Fotografia: usos e funções no século XIX. São Paulo: EDUSP, 1991.

FOUCAULT, M. A ordem do discurso. Aula Inaugural no Collège de France, Pronunciada em 2 de Dezembro de 1970. São Paulo: Loyola, 1971.

. História da loucura na idade clássica. São Paulo: Perspectiva, 1972.

O nascimento da clínica. Rio de Janeiro: Forense Universitária, 1978.

Microfísica do poder. Organização e tradução de Roberto Machado. Rio de

Janeiro: Graal, 1979.

História da sexualidade 1. A vontade de saber. Rio de Janeiro: Graal, 1985.

A arqueologia do saber. Rio de Janeiro: Forense Universitária, 1986.

. Vigiar e punir. Nascimento da Prisão. Rio de Janeiro: Vozes, 1991.

. As palavras e as coisas. São Paulo: Martins Fontes, 1992.

1994.

História da sexualidade 2: o uso dos prazeres. Rio de Janeiro: Jorge Zahar,

História da sexualidade 3: O cuidado de si. Rio de Janeiro: Graal, 1996.

O Sujeito e o Poder. In: RABINOV, Paul; DREYFUS, H. Michel Foucault:

Uma Trajetória Filosófica - para além do estruturalismo e da hermenêutica. Rio de Janeiro: Forense Universitária, 1995, p. 229-249.

Sobre a História da Sexualidade. In: Microfísica do poder. Org. e trad. Roberto Machado. 17 ed. Rio de Janeiro: Graal, 1999, p. 243-276.

Diálogo sobre o poder. Ditos e escritos. Estratégias, Poder-Saber. MOTTA, Manoel Barros da (Org.). Rio de Janeiro: Forense Universitária, 2003. v. 4.

HILSDORF, M. L. S. História da Educação Brasileira. São Paulo: Thompson, 2005. 
HARDT, M.; NEGRI, A. Produção biopolítica. In: Império. Rio de Janeiro: Record, 2001, p. 41-60.

MACHADO, R. Por uma genealogia do poder. In: FOUCAULT, M. Microfísica do poder. Ed: Graal, 1999.

SEVCENKO, N. O prelúdio republicano, astúcias da ordem e ilusões do progresso. In: NOVAIS, F. (Org.). História da vida privada no Brasil República: da belle époque à era do rádio, v. 3, São Paulo: Cia das Letras, 1998.

VIDAL, D. G. A fotografia como fonte para a historiografia educacional sobre o século XIX: uma primeira aproximação. In: FARIA FILHO, L. M. (Org.). Educação, Modernidade e Civilização. Fontes e perspectivas de análises para a história da educação oitocentista. Belo Horizonte: Autêntica, 1998.

Tecendo história ( e recriando memória) da escola primária e da infância no

Brasil: os grupos escolares. In: Grupos escolares: cultura escolar primária e escolarização da infância no Brasil (1893-1971). Campinas, SP: Mercado de Letras, 2006. 